CLINICAL STUDY

\title{
B-cell autoepitopes on the acetylcholinesterase-homologous region of human thyroglobulin: association with Graves' disease and thyroid eye disease
}

\author{
Apollon Thrasyvoulides, Maria Sakarellos-Daitsiotis ${ }^{1}$, George Philippou ${ }^{2}$, Athanasios Souvatzoglou ${ }^{2}$, \\ Constantinos Sakarellos ${ }^{1}$ and Peggy Lymberi \\ Laboratory of Immunology, Hellenic Pasteur Institute, Athens, ${ }^{1}$ Department of Chemistry, University of Ioannina, Ioannina and \\ ${ }^{2} 1$ st Endocrine Section, 'Alexandra' General Hospital, Athens, Greece \\ (Correspondence should be addressed to P Lymberi, Laboratory of Immunology, Hellenic Pasteur Institute, 127 Vasilissis Sofias Avenue, \\ 11521 Athens, Greece; Email: plymberi@mail.pasteur.gr)
}

\begin{abstract}
Objective: Thyroglobulin ( $\mathrm{Tg}$ ) is a large autoantigen involved in autoimmune thyroid diseases. $\mathrm{Tg}$ epitopes have, so far, been identified within large peptides. In the present study, we used small synthetic peptides to finely map serological epitopes on the highly immunogenic C-terminal region of $\mathrm{Tg}$. Homology of this region to acetylcholinesterase (AChE) has been implicated in the pathogenesis of thyroid eye disease (TED) through cross-reactive antibodies.

Methods: We tested total IgG purified from four pilot Graves' disease (GD) sera reactive with both Tg and AChE and from three healthy controls, for reactivity against overlapping 20mer peptides (pin synthesis) covering the sequence 2171-2748 of human Tg. Antibody-reactive peptides were subsequently synthesized by a solid-phase technique for confirmation with a large number of sera: 99 GD, 32 Hashimoto's thyroiditis (HT) and 45 healthy controls.

Results: Peptides TgP15, TgP26 and TgP41 (amino acids 2339-2358, 2471-2490 and 2651-2670 respectively) were found to be targets of autoantibodies on intact $\mathrm{Tg}$, recognized by a statistically significant proportion of GD sera $(22.2 \%, 35.4 \%$ and $30.3 \%$ respectively), compared with HT $(0 \%$, $15.6 \%$ and $6.3 \%$ respectively) and healthy controls $(0 \%, 4.4 \%$ and $4.4 \%$ respectively). The majority of GD sera $(56.6 \%)$ were positive for at least one of the three peptides. In GD, TgP2 6 reactivity was found to be associated with TED (48.6\% with TED versus $25.5 \%$ without TED, $P<0.05)$.

Conclusion: Some epitopes on the C-terminal region of Tg are associated with GD. A subset of Tgreactive autoantibodies, directed to this region, is associated with TED and may be involved in the development of the disease.
\end{abstract}

European Journal of Endocrinology 145 119-127

\section{Introduction}

Thyroglobulin (Tg), a homodimeric glycosylated iodoprotein $(2 \times 330 \mathrm{kDa})$ produced by the thyroid gland, serves as a precursor for the thyroid hormones thyroxine and 3,5,3'-triiodothyronine (1). Autoantibodies to $\mathrm{Tg}$ have been particularly useful for the diagnosis of autoimmune thyroid diseases, such as Graves' disease (GD) and Hashimoto's thyroiditis (HT) $(2)$, but their pathogenic role is still debatable $(3,4)$. Several epitopes recognized by these autoantibodies or by Tg-induced antibodies in animals have been characterized throughout the $\mathrm{Tg}$ sequence (5-9). Either large recombinant peptides (5-8) or proteolytic fragments (9) have been used to map serological epitopes on $\mathrm{Tg}$; small synthetic peptides have not been used so far due to the large size of the protein. The
C-terminal region of $\mathrm{Tg}$ is highly immunogenic and encompasses four of the five pathogenic T-cell epitopes known in animal studies (10). Moreover, this portion of $\mathrm{Tg}$ (2171-2748 of human $\mathrm{Tg}$ ) shares significant sequence homology (28\%) (11) and a common folding pattern $(12,13)$ with the catalytic subunit of acetylcholinesterase (AChE), an enzyme of the cholinergic synapses of the central and peripheral nervous systems $(14,15)$ (homology reaches $64 \%$ between segments 2314-2360 of human $\mathrm{Tg}$ and 147-197 of Torpedo californica AChE (16)). AChE has two molecular forms, the globular and the asymmetric, both containing catalytic subunits, while the asymmetric form also contains a filamentous tail (17).

Thyroid eye disease (TED) is commonly associated with autoimmune thyroid diseases, especially with GD, although the pathogenic mechanism remains 
unknown. Several theories have been formulated about the pathogenesis of TED (18-21). Based on the structural homology between $\mathrm{Tg}$ and AChE, Ludgate et al. (22) suggested the pathogenic role of autoantibodies cross-reacting with $\mathrm{Tg}$ and orbital muscle AChE. Eye-specificity of these antibodies could be explained since orbital muscle AChE may be different from that of skeletal muscle $(23,24)$. In a previous study, we showed that immunoglobulin G (IgG) antibodies reacting with both $\mathrm{Tg}$ and $\mathrm{AChE}$ are present in a significant proportion of GD patients and are associated with TED (25). Furthermore, an 89-amino acid (a.a.)long recombinant peptide of human Tg (2376-2464) was found to bear a $\mathrm{Tg} / \mathrm{AChE}$ shared epitope, since it was recognized by rabbit anti-AChE antibodies (5). Antibodies binding to this epitope were present in a higher proportion of patients with GD than with HT, although their levels did not correlate closely with the presence of TED (24).

In the present study, we used 20mer overlapping synthetic peptides spanning the highly immunogenic and AChE-homologous C-terminal region of human $\mathrm{Tg}$, to finely map $\mathrm{Tg}$ epitopes associated with autoimmune thyroid diseases and particularly with TED.

\section{Subjects and methods}

\section{Patients}

Sera from 99 patients with GD (mean age 48 years, range 17-84 years, female/male 74/25) and 32 patients with HT (mean age 43 years, range 15-78 years, female/male 28/4) were used. The diagnosis of patients was based on conventional clinical criteria and laboratory findings. Patients were subjected to detailed clinical examination regarding TED, including measurement of exophthalmos. In those patients where ophthalmopathy was not clinically evident, orbital echography was performed in order to ascertain the orbital muscle involvement. Among GD patients, 37 presented TED of grade II-IV, according to Werner's modification of the American Thyroid Association classification $(26,27), 55$ did not present TED, while for 7 , data were not available. Seventy-eight out of ninety-nine GD patients $(78.8 \%)$ were thyroid-binding inhibiting immunoglobulins (TBII) positive as determined by a radio-receptor assay (Biocode Biotechnology, Sclessin-Liege, Belgium). No correlation was observed between TED and TBII positivity. Moreover, 45 sera from healthy controls (mean age 45 years, range 20-75 years, female/male 35/10), without thyroid disorder were used. All sera were stored in aliquots at $-70{ }^{\circ} \mathrm{C}$ until use.

\section{Reagents}

Human Tg was purified from thyroid glands, obtained at operations, applying a well-established methodology
(28). AChE from Electrophorus electricus (approx. $1000 \mathrm{U} / \mathrm{mg}$ ) was purchased from Boehringer (Mannheim, Germany). Both antigen preparations were checked for purity by SDS-PAGE, under reducing and non-reducing conditions (29). Anti-human $\gamma$ chain antibodies coupled to peroxidase or alkaline phosphatase were purchased from Sigma (St Louis, MO, USA).

\section{Synthetic peptides}

Pin-bound peptides Forty-eight sequential 20mer peptides ( $\mathrm{TgP} 1-48)$ overlapping by eight residues and covering the sequence $2171-2748$ of human $\mathrm{Tg}$ (numbering of mature protein, not including the signal peptide) were prepared in duplicate according to the method of Geysen et al. (30), on prederivatized polyethylene pins (Chiron, Clayton, Australia). The synthesis protocol was based on the principles of solidphase peptide synthesis (31) and the 9-fluorenylmethoxycarbonyl (Fmoc) protecting group strategy was followed.

Solid-phase synthesized peptides The peptides $\mathrm{TgP} 15$, $\mathrm{TgP} 26$ and $\mathrm{TgP} 41$, in free form, were synthesized according to standard solid-phase methods by Genosys Biotechnologies (Cambridge, UK). Peptide purity was assessed by HPLC and mass spectroscopic analysis.

\section{Isolation of total serum IgG}

Total IgG was purified on a protein G-Sepharose column (Pharmacia, Uppsala, Sweden) from four GD and three healthy control sera according to established methodology. Briefly, the serum passed through the column for $2 \mathrm{~h}$, then the column was washed with

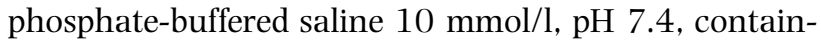
ing $150 \mathrm{mmol} / \mathrm{l} \mathrm{NaCl}$ (PBS). Bound IgG was eluted with $0.1 \mathrm{~mol} / \mathrm{l} \mathrm{HCl-glycine} \mathrm{pH} 2.2$, at $4{ }^{\circ} \mathrm{C}$ and neutralized adding $2 \mathrm{~mol} / \mathrm{l}$ Tris. Fractions containing IgG (absorbance measured at $280 \mathrm{~nm}$ ) were concentrated and dialyzed against PBS. The IgG was stored in $50 \%$ glycerol, at $-20{ }^{\circ} \mathrm{C}$.

\section{Anti-Tg depletion and isolation of specific antibodies}

Anti-Tg antibodies were depleted from the total IgG fraction on a $\mathrm{Tg}$ immunoadsorbent $(4 \mathrm{mg} \mathrm{Tg}$ per $\mathrm{ml}$ beads); purified human Tg was coupled to glutaraldehyde-activated polyacrylamide-agarose beads, Ultrogel AcA22 (IBF biotechnics, Villeneuve-la-Garenne, France), as described previously (32). The efficiency of anti-Tg depletion was confirmed by ELISA. Anti-Tg antibodies were subsequently eluted from the immunoadsorbent with $0.2 \mathrm{~mol} / \mathrm{l} \mathrm{HCl-glycine} \mathrm{pH} 2.2$, at $4{ }^{\circ} \mathrm{C}$. After neutralization, concentration and dialysis 
against PBS, the anti-Tg fraction was stored in 50\% glycerol, at $-20{ }^{\circ} \mathrm{C}$.

\section{ELISA}

Non-competitive ELISA with pin-bound peptides Peptides covalently attached to polyethylene supports were tested for antibody binding by ELISA in 96-well microtitration plates. Purified IgG (instead of whole sera) was used to test reactivity against pin-bound peptides in order (a) to reduce the non-specific binding observed with the use of whole serum and (b) to avoid possible peptide damage by serum proteases. Pins were immersed in PBS containing $0.3 \%$ Tween-20, $1 \%$ bovine serum albumin and $1 \%$ ovalbumin, for $1 \mathrm{~h}$ at room temperature, to block free binding sites. Serum IgG, diluted in the above buffer, was added to the wells and incubated overnight at $4{ }^{\circ} \mathrm{C}$. In optimization experiments, the screening concentration of $50 \mu \mathrm{g} / \mathrm{ml} \mathrm{IgG}$ was deemed to maximize the differences between positive and negative wells and it was therefore used throughout the study (affinity-purified $\mathrm{Tg}$-specific antibodies were used at a screening concentration of $5 \mu \mathrm{g} / \mathrm{ml}$ ). After washing with PBS containing $0.5 \%$ Tween-20, anti-human $\gamma$-peroxidase conjugate $(1 \mu \mathrm{g} / \mathrm{ml}$ in blocking buffer) was added and incubated for $1 \mathrm{~h}$ at room temperature. The pins were again washed and the binding of antibodies was detected by the addition of enzyme substrate $\left(\mathrm{H}_{2} \mathrm{O}_{2}+2,2^{\prime}\right.$ azino-bis-3-ethylbenzothiazoline sulfonic acid: ABTS). The absorbance of the color was measured at $405 \mathrm{~nm}\left(\mathrm{~A}_{405} \mathrm{~nm}\right)$. Bound antibodies were removed from the pins by sonication in $0.1 \mathrm{~mol} / \mathrm{l} \mathrm{NaH} \mathrm{PO}_{4}, 1 \%$ SDS and $0.1 \% 2$-mercaptoethanol, for $30 \mathrm{~min}$ at $60{ }^{\circ} \mathrm{C}$. In order to determine whether bound antibodies were completely removed, pins were incubated with antihuman $\gamma$-peroxidase conjugate followed by the addition of substrate solution $\left(\mathrm{H}_{2} \mathrm{O}_{2}+\mathrm{ABTS}\right)$. In all cases the final $\mathrm{A}_{405} \mathrm{~nm}$ was equal to the background. The cut-off point of positivity was calculated for each peptide as the mean $A_{405} \mathrm{~nm}$ values +3 s.D. of serum IgG from the healthy controls. With this method only the serum IgG of one patient can be tested (in duplicate) each time for reactivity against the panel of 48 pin-bound peptides. Therefore, the method should be considered only as a screening method for the detection of target peptides.

Non-competitive ELISA with immobilized antigens ELISA plates, Maxisorb (Nunc, Roskilde, Denmark), were coated overnight at $4{ }^{\circ} \mathrm{C}$ with $\mathrm{Tg}$ or AChE, or each of the peptides $(10 \mu \mathrm{g} / \mathrm{ml}, 100 \mu \mathrm{l}$ per well $)$, in $0.1 \mathrm{~mol} /$ l carbonate-bicarbonate buffer $\mathrm{pH}$ 9.6. Free binding sites were blocked with PBS containing $5 \%$ bovine serum (PBS-BS) for $45 \mathrm{~min}$ at $37^{\circ} \mathrm{C}$. Sera, diluted (1:50) in PBS-BS containing 0.1\% Tween-20 (PBS-BS$\mathrm{T})$, were added to the wells in duplicates and incubated with immobilized antigen. In ELISA with immobilized $\mathrm{Tg}$ or AChE, this incubation lasted $90 \mathrm{~min}$ at $37^{\circ} \mathrm{C}$, while for the immobilized peptides the incubation was performed overnight at $4{ }^{\circ} \mathrm{C}$. The plates were then incubated with anti-human $\gamma$-alkaline phosphatase conjugate $\left(0.5 \mu \mathrm{g} / \mathrm{ml}\right.$ in PBS-BS-T) for $1 \mathrm{~h}$ at $37^{\circ} \mathrm{C}$. After each step the plates were extensively washed with PBS containing $0.1 \%$ Tween-20. The assay was completed by the addition of the enzyme substrate ( $p$-nitrophenyl phosphate). The absorbance of the produced color was read spectrophotometrically at $405 \mathrm{~nm}\left(\mathrm{~A}_{405 \mathrm{~nm}}\right)$. Absorbance of experimental wells was calculated after subtraction of the background determined in the absence of coated antigen. The cutoff point of positivity was calculated as the mean $\mathrm{A}_{405 \mathrm{~nm}}$ values of the healthy control sera +2.5 S.D. Serum antibody activity was expressed in units (cut-off point $=100$ units). Sera with a reactivity equal to the cut-off point were included in each assay to compensate for interassay variation.

Competitive ELISA Binding of sera to immobilized AChE was checked for inhibition by soluble peptides $\mathrm{TgP} 26$ and $\mathrm{TgP} 41$. The same procedure was followed as for the non-competitive ELISA with the difference that the serum (at a dilution corresponding to $50 \%$ of maximum binding) had been preincubated with soluble peptide $(\mathrm{TgP} 26$ or $\mathrm{TgP} 41$, at $1.6-50 \mathrm{nmol} / \mathrm{ml})$ for $90 \mathrm{~min}$ at $37^{\circ} \mathrm{C}$, before being placed into the AChEcoated wells. The results were expressed as inhibition percent $(\%)$ plotted versus concentration of inhibitor $(\mathrm{nmol} / \mathrm{ml})$.

\section{Statistical analysis}

The proportions of positive sera in the patients' groups were compared with each other as well as with that in the healthy control group, using a $\chi^{2}$ test of homogeneity. The same test was used to compare the two subgroups of GD patients (with and without TED). A $P$ value less than 0.05 was considered statistically significant.

\section{Results}

\section{Epitope mapping on the AChE-homologous region of $\mathrm{Tg}$}

Forty-eight 20mer peptides overlapping by eight residues and covering the C-terminal portion of $\mathrm{Tg}$ (sequence 2171-2748 of human $\mathrm{Tg}$ ) were prepared in duplicate on polyethylene pins. Total IgG was purified from sera of four pilot GD patients, which were previously found to react with both $\mathrm{Tg}$ and $\mathrm{AChE}$ (25). Total serum IgG was also purified from three healthy donors used as a control. IgG $(50 \mu \mathrm{g} / \mathrm{ml})$ was tested by ELISA for reactivity against the synthetic 


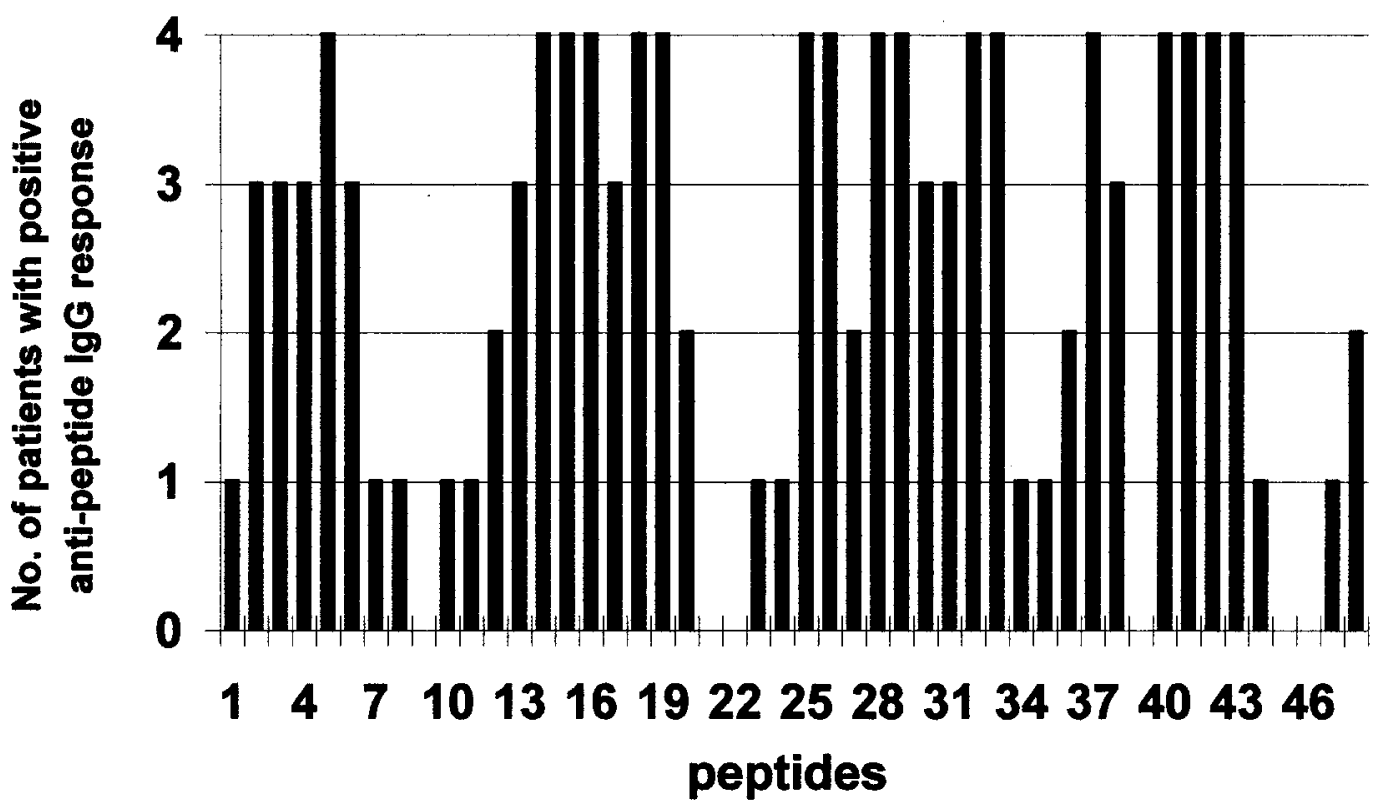

Figure 1 Number of positive IgG preparations $(50 \mu \mathrm{g} / \mathrm{ml})$ from GD patients for each of the pin-bound peptides. The cut-off point of positivity was calculated for each peptide as the mean $A_{405} \mathrm{~nm}$ values +3 S.D. of serum IgG from the three healthy controls.

peptides. Seventeen out of the forty-eight peptides were recognized by all four GD IgG preparations, nine of the peptides were recognized by three of them, nine of the peptides were recognized by two of them and eleven of the peptides were recognized by one of them (Fig. 1). None of the total serum IgG was positive for six of the peptides tested. Interestingly, no immunodominant region was identified and the peptides recognized by a high proportion of GD IgG preparations were spread throughout the examined portion of $\mathrm{Tg}$.

To ascertain which peptides encompass epitopes on intact $\mathrm{Tg}$, we proceeded to deplete anti-Tg antibodies from total IgG of two GD patients, by immunoadsorption on a Tg-affinity column. The anti-peptide reactivity of total IgG was compared with that of anti-Tg-depleted IgG (Fig. 2). The greatest decrease of reactivity after depletion of Tg-specific IgG, common for both GD patients, was observed for peptides $\mathrm{TgP} 15, \mathrm{TgP} 26$ and $\mathrm{TgP} 41$. The segments of human $\mathrm{Tg}$ corresponding to the above peptides are $2339-2358,2471-2490$ and 2651-2670, while their respective amino acid sequences are QVAALTWVQTHIRGFGGDPR, PPARALKRSLWVEVDLLIGS and PYEFSRKVPTFATPWPDFVP. These data suggested that these peptides are likely epitopes on intact $\mathrm{Tg}$ recognized by autoantibodies.

To confirm this finding, $\mathrm{Tg}$-specific IgG was purified by immunoaffinity from serum IgG fractions of two GD patients and further tested (at $5 \mu \mathrm{g} / \mathrm{ml}$ ) for reactivity against five pin-bound peptides, selected according to the previous test (Fig. 2): $\mathrm{TgP} 15, \mathrm{TgP} 26$ and $\mathrm{TgP} 41$ (for which the reactivity was expected to be high) and
$\mathrm{TgP} 21$ and $\mathrm{TgP} 44$ (for which a very low reactivity was expected). As shown in Fig. 3, the expected anti-peptide reactivity was confirmed.

\section{Reactivity of sera against TgP15, TgP26 and TgP41}

The peptides $\operatorname{TgP} 15, \operatorname{TgP} 26$ and $\mathrm{TgP} 41$, synthesized in free form by a solid-phase technique, were used in ELISA for screening of a large number of sera (99 GD, 32 HT and 45 healthy controls). The anti-peptide reactivity of individual GD, HT and healthy control sera are shown in Fig. 4. Among 99 GD sera tested, 22 were positive for $\mathrm{TgP} 15(22.2 \%), 35$ for $\mathrm{TgP} 26(35.4 \%)$ and 30 for $\mathrm{TgP} 41(30.3 \%)$. Among patients with HT, none of the 32 sera was positive for $\mathrm{TgP} 15(0 \%)$, five sera were positive for $\operatorname{TgP} 26(15.6 \%)$ and only two for $\mathrm{TgP} 41(6.3 \%)$. None of the 45 healthy controls was positive for $\operatorname{TgP} 15(0 \%)$, while a positive reaction was exhibited by two healthy controls for $\mathrm{TgP} 26$ and two for $\mathrm{TgP} 41(4.4 \%)$ (Table 1). Overall, $56.6 \%$ of GD sera were positive for at least one of the three peptides, in contrast to $21.9 \%$ and $8.9 \%$ in HT and healthy controls respectively. Statistically significant differences were found between GD and HT $(P<0.001)$ as well as between GD and healthy controls $(P<0.001)$, but not between HT and healthy controls (Table 1). 

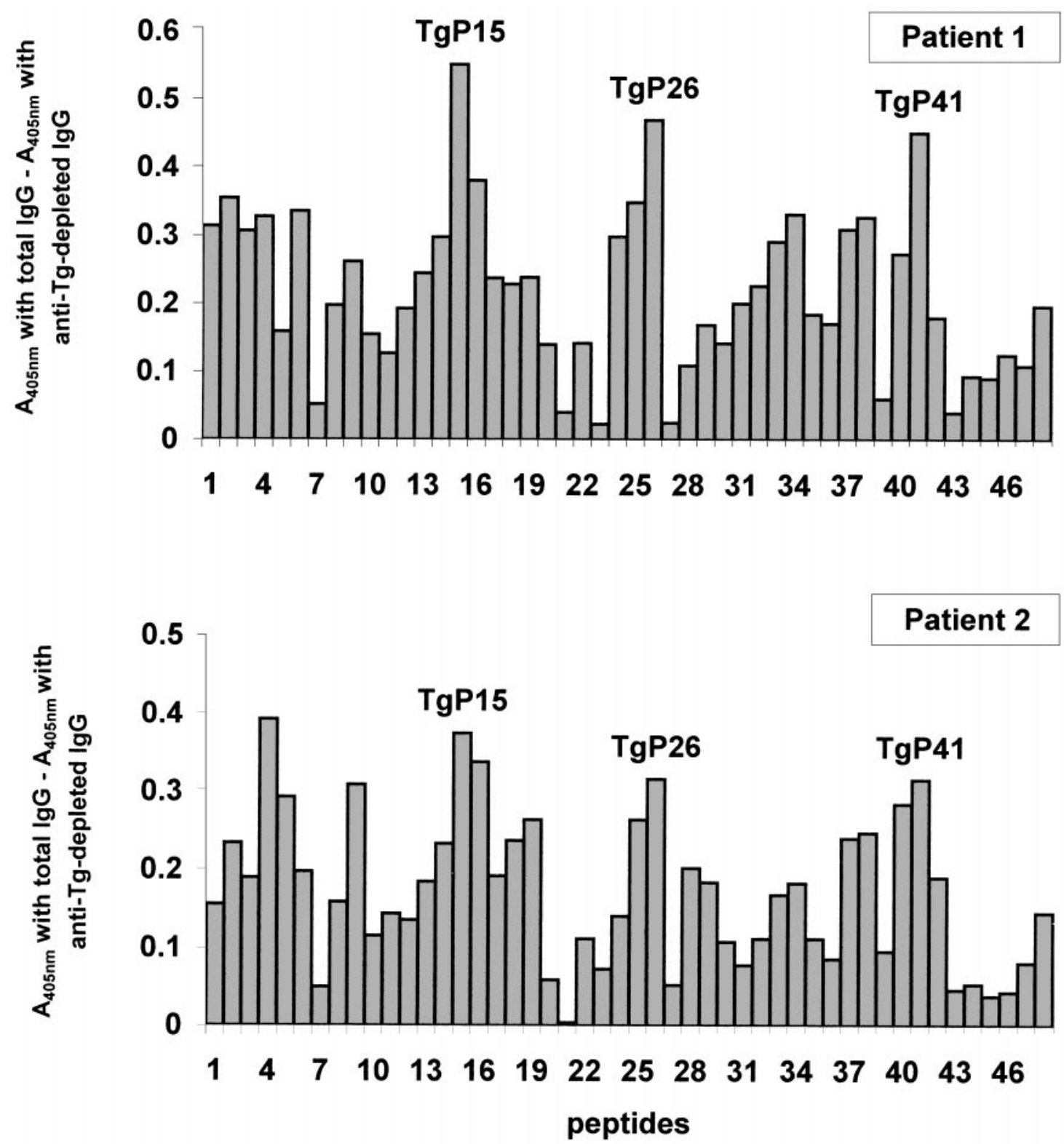

Figure 2 Differences in $A_{405} \mathrm{~nm}$ values before and after depletion of anti-Tg antibodies from the total IgG, for two patients with GD (1 and 2). IgG before and after anti-Tg depletion was tested at $50 \mu \mathrm{g} / \mathrm{ml}$ against the pin-bound peptides shown.

\section{Correlation of serum anti-peptide reactivity with TED}

Within the GD group, 37 patients also presented TED and 55 showed no evident TED. When the above data were analyzed according to the presence of TED, it was found that 17 of the 37 sera $(48.6 \%)$ from GD patients with TED reacted with TgP26, whereas only 14 of the 55 sera $(25.5 \%)$ from GD patients without TED reacted with the same peptide (Table 1). This is a statistically significant difference $(P<0.05)$, revealing an association of anti-TgP26 reactivity with TED. Reactivity against $\mathrm{TgP} 15$ and $\mathrm{TgP} 41$ was not associated with TED (Table 1).

\section{Inhibition of anti-AChE reactivity by soluble peptide TgP26}

Ten GD sera, reactive with $\mathrm{TgP} 26$, were chosen to check the inhibition of their reactivity to immobilized AChE by the soluble peptide TgP 26. Antibody binding in two of these sera was inhibited by up to $45 \%$ for one of them and $50 \%$ for the other, at peptide 

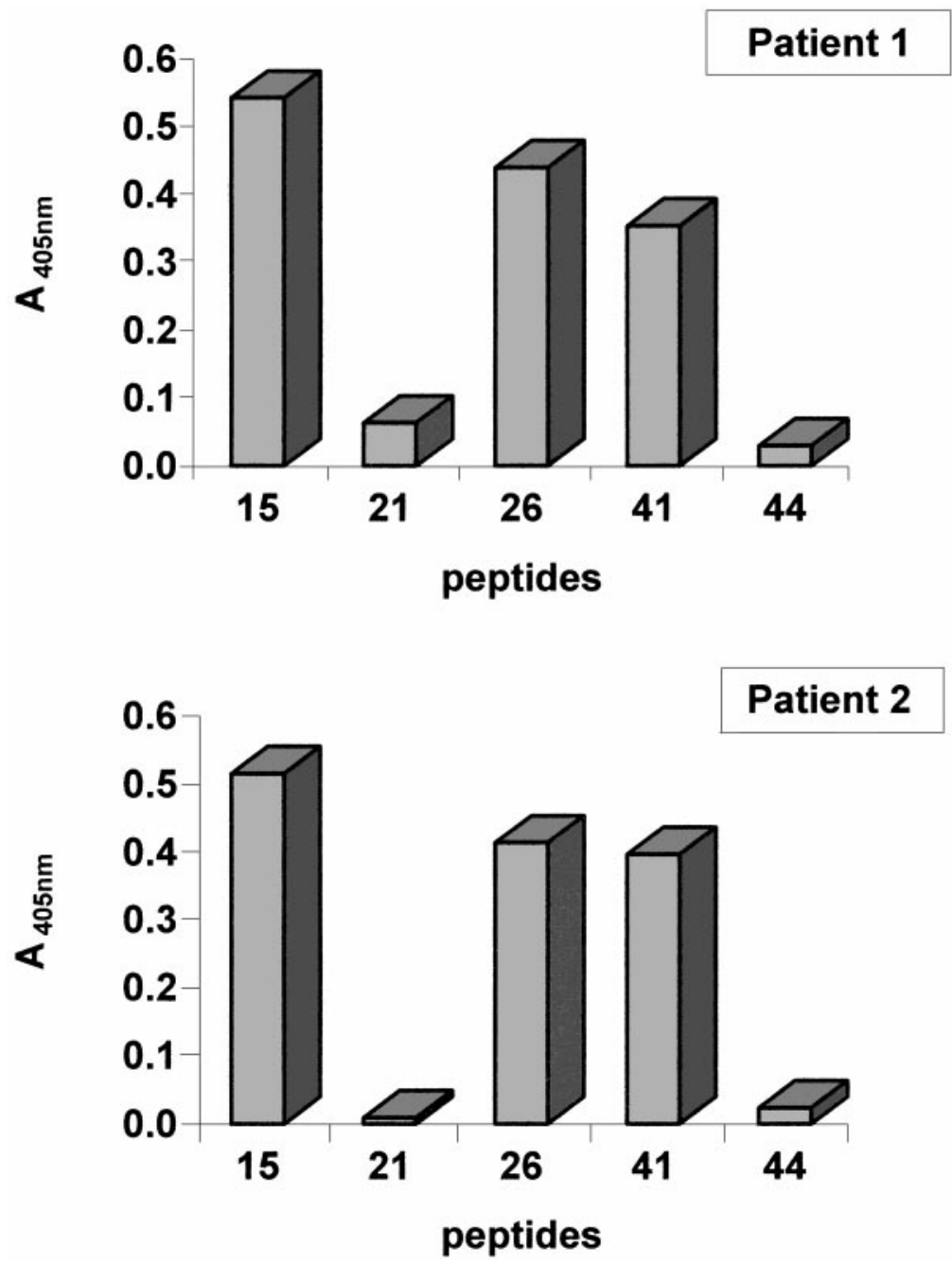

Figure 3 Reactivity of affinity purified anti-Tg antibodies $(5 \mu \mathrm{g} / \mathrm{ml})$ from two patients with GD (1 and 2) against selected peptides of human $\mathrm{Tg}$. concentrations of $50 \mathrm{nmol} / \mathrm{ml}$ (Fig. 5), whereas in the other eight sera no inhibition was observed at concentrations up to $50 \mathrm{nmol} / \mathrm{ml}$. Soluble $\mathrm{TgP} 41$ peptide was used as a negative control. Antibodybinding to AChE was not inhibited by TgP41 in any of the sera tested.

\section{Discussion}

Due to the large size of $\mathrm{Tg}$, the identification of antigenic sequences on $\mathrm{Tg}$, recognized by diseaseassociated or Tg-induced antibodies in animals, has so far been accomplished using either large recombinant peptides (5-8) or proteolytic fragments (9). In the present study, we used small synthetic peptides spanning the AChE-homologous C-terminal portion of human $\mathrm{Tg}$ (a.a. 2171-2748) to identify serological epitopes targeted by IgG, isolated from $\mathrm{Tg} / \mathrm{AChE}-$ reacting GD sera. No immunodominant region was identified within the examined portion of $\mathrm{Tg}$, since the peptides (defining linear epitopes) recognized by all four
GD IgG preparations tested were spread throughout the sequence. Using proteolytic fragments or denatured $\mathrm{Tg}$, some researchers concluded that the main $\mathrm{Tg}$ autoepitopes are mostly conformational, since only native $\mathrm{Tg}$ or large $\mathrm{Tg}$ fragments are recognized by autoantibodies (33-35). This discrepancy could be explained by the non-immunodominant nature of linear epitopes and because these epitopes may be masked or destroyed when $\mathrm{Tg}$ is denatured or digested with enzymes.

We identified the peptides $\mathrm{TgP} 15, \mathrm{TgP} 26$ and $\mathrm{TgP} 41$ as the most likely epitopes recognized on intact $\mathrm{Tg}$. In their free form, these peptides were recognized by a significant proportion $(22-35 \%)$ but not by the majority of GD sera, although more than half of GD sera $(56.6 \%)$ were positive for at least one of the three peptides. Our results confirm those of other researchers (36) showing that Tg-immunodominant epitopes are conformational.

Increased serum anti-TgP 26 reactivity of GD patients was statistically associated with the presence of TED. Previous studies had demonstrated the presence of 

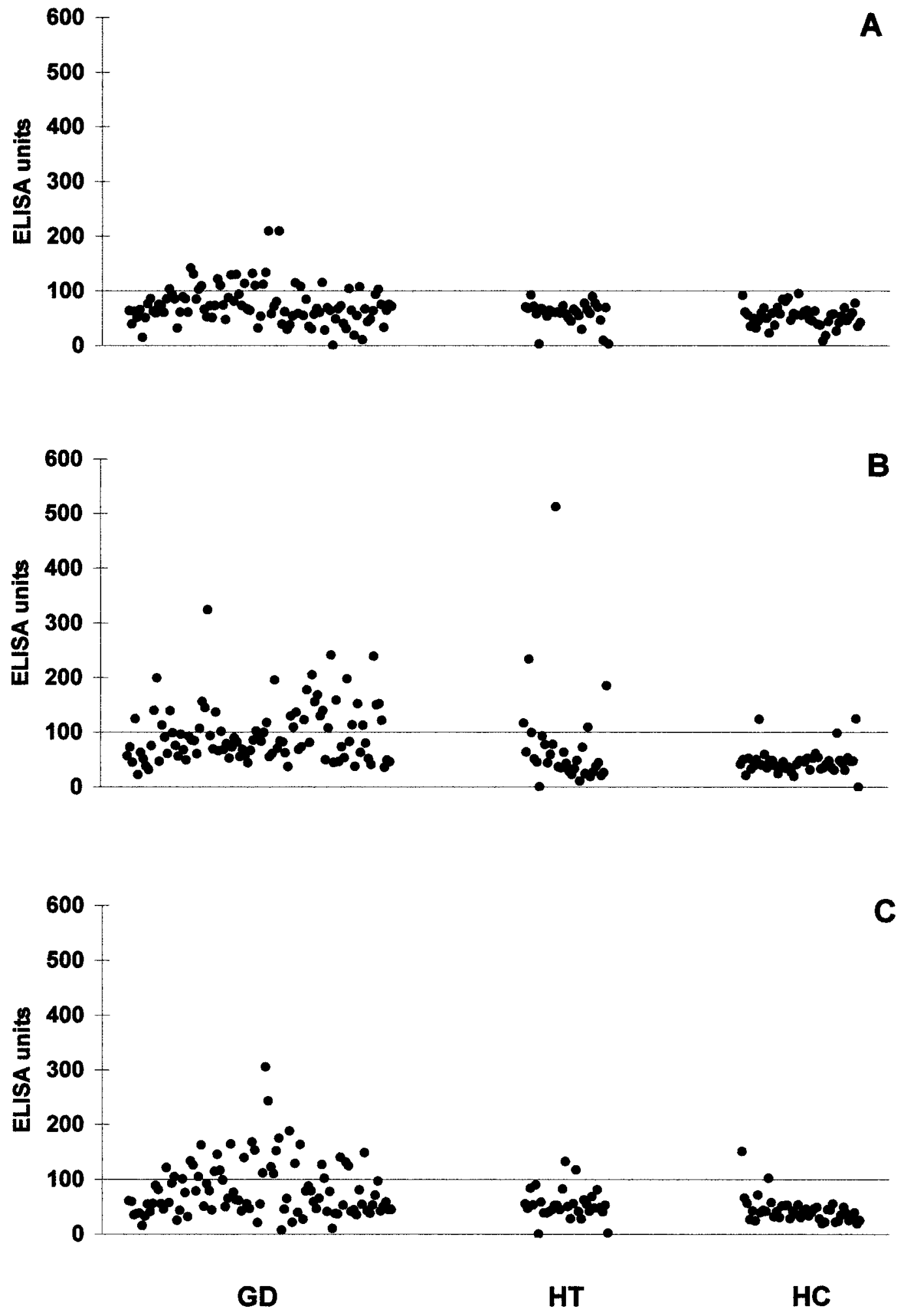

Figure 4 Distribution of reactivity values (ELISA units) against (A) TgP15, (B) TgP26 and (C) TgP41 of the sera (at 1/50 dilution) from the three groups tested: Graves' disease (GD), Hashimoto's thyroiditis (HT) and healthy controls (HC). The cut-off point (calculated as the mean $A_{405} \mathrm{~nm}$ values of the healthy control sera +2.5 S.D.) is indicated by horizontal lines. 
Table 1 Incidence of peptide-positive sera from Graves' disease (GD), Hashimoto's thyroiditis (HT) and healthy controls (HC).

\begin{tabular}{|c|c|c|c|c|c|c|c|c|c|c|}
\hline Peptide & $\begin{array}{l}\text { Amino acid } \\
\text { sequence }\end{array}$ & $\begin{array}{l}\text { GD (\%) } \\
(n=99)\end{array}$ & $\begin{array}{l}\text { HT }(\%) \\
(n=32)\end{array}$ & $\begin{array}{l}\text { HC (\%) } \\
(n=45)\end{array}$ & $\begin{array}{l}\text { GD with } \\
\text { TED (\%) } \\
(n=37)\end{array}$ & $\begin{array}{l}\text { GD without } \\
\text { TED (\%) } \\
(n=55)\end{array}$ & $\begin{array}{c}\boldsymbol{P}^{*} \\
\text { GD-HT }\end{array}$ & $\underset{\text { GD-HC }}{P}$ & $\underset{\mathrm{HT}-\mathrm{HC}}{\boldsymbol{P}}$ & $\begin{array}{c}\boldsymbol{P} \\
\text { GD with/without } \\
\text { TED }\end{array}$ \\
\hline TgP15 & $2339-2358$ & 22.2 & 0 & 0 & 16.2 & 23.6 & $<0.005$ & $<0.001$ & NS & NS \\
\hline TqP26 & $2471-2490$ & 35.4 & 15.6 & 4.4 & 48.6 & 25.5 & $<0.05$ & $<0.001$ & NS & $<0.05$ \\
\hline TgP41 & $2651-2670$ & 30.3 & 6.3 & 4.4 & 21.6 & 36.4 & $<0.01$ & $<0.001$ & NS & NS \\
\hline $\begin{array}{l}\text { At least } \\
\text { one peptide }\end{array}$ & & 56.6 & 21.9 & 8.9 & - & - & $<0.001$ & $<0.001$ & NS & - \\
\hline
\end{tabular}

*Statistical comparison among GD, HT and HC sera, as well as between GD sera with and without thyroid eye disease (TED). $P$ values were deducted from the $\chi^{2}$ test. NS, differences not statistically significant. ${ }^{\star \star} T g P 15,26$ or 41.

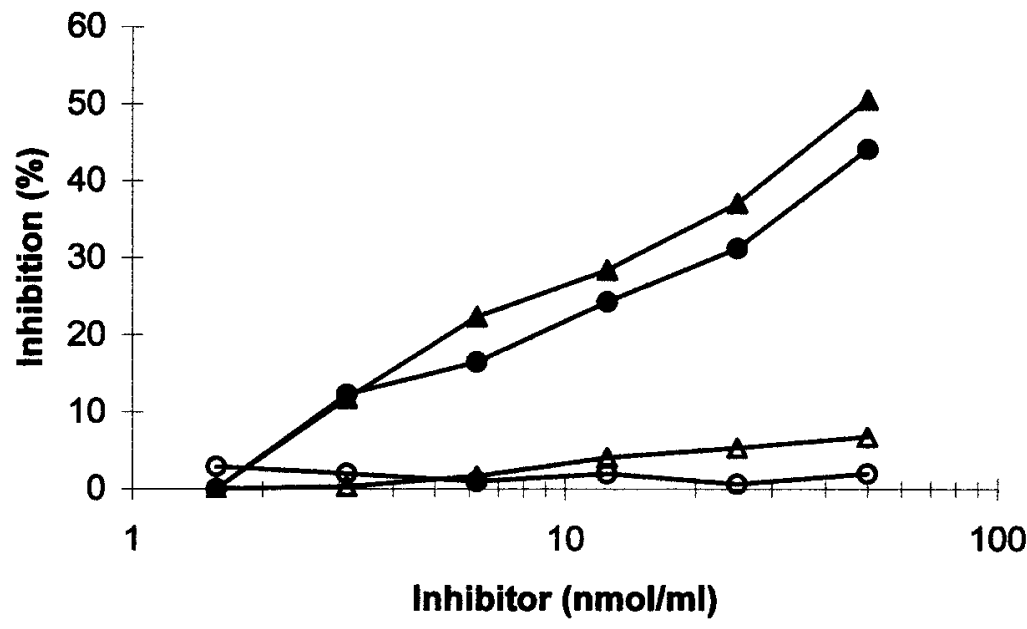

Figure 5 Inhibition of binding to immobilized AChE of two TgP26-reactive GD sera (1 and 2), by soluble peptides TgP26 ( $\boldsymbol{\Lambda}$ and $\bullet$ for serum 1 and 2 respectively) and $\operatorname{TgP} 41(\triangle$ and $\bigcirc$ for serum 1 and 2 respectively). The graph indicates percentage of inhibition plotted versus concentration of inhibitor. common epitope(s) between $\mathrm{Tg}$ and $\operatorname{AChE}(5,24,25)$, which may be involved in the pathogenesis of TED. Within the 20 a.a. sequence of $\mathrm{TgP} 26$, three amino acids are shared and five are conservative substitutions in the homologous sequence of human AChE (37). Binding to AChE was inhibited by soluble TgP26 in the case of two out of the ten tested TgP26-reactive GD sera. This result suggests that $\mathrm{TgP} 26$ comprises a $\mathrm{Tg} /$ AChE common epitope. The low incidence found can be explained, since (a) blockade of a subgroup of AChEreactive autoantibodies (those directed against the TgP26-homologous site on AChE) will not significantly influence anti-AChE reactivity, and (b) the affinity of the autoantibodies is possibly higher for the protein than for the 20mer peptide. The epitopes defined by the peptides TgP15 and TgP26 do not overlap with previously characterized autoepitopes or heteroepitopes on $\mathrm{Tg}$ (5-9). The sequence of $\mathrm{TgP} 41$ is encompassed in the segment 2644-2730 of human Tg, bearing a heteroepitope (6), and comprises an overlap of 14 residues with the sequence 2657-2748 of human $\mathrm{Tg}$, recognized by a few HT sera (9).

In conclusion, we identified three epitopes on the C-terminal region of $\mathrm{Tg}$ serologically differentiating GD from HT. One of these epitopes was found to be associated with TED. Studies are in progress in order to assess the pathogenicity, if any, of this epitope.

\section{Acknowledgements}

The authors are grateful to Dr G Carayanniotis for useful discussions and critical reading of the manuscript. We also thank Dr V Tsikaris for useful advice concerning peptide synthesis.

\section{References}

1 Malthiery Y, Marriq C, Berge-Lefranc JL, Franc JL, Henry M, Lejeune PJ et al. Thyroglobulin structure and function: recent advances. Biochimie 198971 195-209.

2 Weetman AP \& McGregor AM. Autoimmune thyroid disease: developments in our understanding. Endocrine Reviews 19845 309-355.

3 Inoue K, Niesen N, Milgrom F \& Albini B. Transfer of experimental autoimmune thyroiditis by in situ perfusion of thyroids with immune sera. Clinical Immunology and Immunopathology 199366 11-17.

4 Tomer Y. Anti-thyroglobulin autoantibodies in autoimmune thyroid diseases: cross-reactive or pathogenic? Clinical Immunology and Immunopathology 199782 3-11. 
5 Ludgate M, Dong Q, Dreyfus PA, Zakut H, Taylor P, Vassart G et al. Definition, at the molecular level, of a thyroglobulin-acetylcholinesterase shared epitope: study of its pathophysiological significance in patients with Graves' ophthalmopathy. Autoimmunity 19893 167-176.

6 Dong Q, Ludgate $M$ \& Vassart G. Towards an antigenic map of human thyroglobulin: identification of ten epitope-bearing sequences within the primary structure of thyroglobulin. Journal of Endocrinology 1989122 169-176.

7 Henry M, Malthiery Y, Zanelli E \& Charvet B. Epitope mapping of human thyroglobulin. Journal of Immunology 19901453692 3698.

8 Henry M, Zanelli E, Piechaczyk M, Pau B \& Malthiery Y. A major human thyroglobulin epitope defined with monoclonal antibodies is mainly recognized by human autoantibodies. European Journal of Immunology 199222 315-319.

9 Saboori AM, Rose NR \& Burek CL. Amino acid sequence of a tryptic peptide of human thyroglobulin reactive with sera of patients with thyroid diseases. Autoimmunity 199522 87-94.

10 Carayanniotis G \& Rao VP. Searching for pathogenic epitopes in thyroglobulin: parameters and caveats. Immunology Today 1997 18 83-88.

11 Schumacher M, Camp S, Maulet Y, Newton M, MacPheeQuigley K, Taylor SS et al. Primary structure of Torpedo californica acetylcholinesterase deduced from its cDNA sequence. Nature $1986319407-409$.

12 MacPhee-Quigley K, Vedvick TS, Taylor P \& Taylor SS. Profile of the disulfide bonds in acetylcholinesterase. Journal of Biological Chemistry 1986261 13565-13570.

13 Swillens S, Ludgate M, Mercken L, Dumont JE \& Vassart G. Analysis of sequence and structure homologies between thyroglobulin and acetylcholinesterase: possible functional and clinical significance. Biochemical and Biophysical Research Communications $1986137142-148$.

14 Bon S, Cartaud J \& Massoulie J. The dependence of acetylcholinesterase aggregation at low ionic strength upon a polyanionic component. European Journal of Biochemistry 1978 $851-14$.

15 Futerman AH, Fiorini RM, Roth E, Low MG \& Silman I. Physicochemical behaviour and structural characteristics of membrane-bound acetylcholinesterase from Torpedo electric organ. Biochemical Journal 1985226 369-377.

16 Malthiery $\mathrm{Y}$ \& Lissitzky S. Primary structure of human thyroglobulin deduced from the sequence of its 8448-base complementary DNA. European Journal of Biochemistry 1987 $165491-498$.

17 Schumacher M, Camp S, Maulet Y, Newton M, MacPheeQuigley K, Taylor SS et al. Primary structure of acetylcholinesterase: implications for regulation and function. Federation Proceedings 198645 2976-2981.

18 Salvi M, Miller A \& Wall JR. Human orbital tissue and thyroid membranes express a $64 \mathrm{kDa}$ protein which is recognized by autoantibodies in the serum of patients with thyroid-associated ophthalmopathy. FEBS Letters 1988232 135-139.

19 Wall JR, Hayes M, Scalise D, Stolarski C, Nebes V, Kiljanski J et al. Native gel electrophoresis and isoelectric focusing of a 64kilodalton eye muscle protein shows that it is an important target for serum autoantibodies in patients with thyroidassociated ophthalmopathy and not expressed in other skeletal muscle. Journal of Clinical Endocrinology and Metabolism 1995 80 1226-1232.

20 Gunji K, Kubota S, Swanson J, Kiljanski J, Bednarczuk T, Wengrowicz $\mathrm{S}$ et al. Role of the eye muscles in thyroid eye disease: identification of the principal autoantigens. Thyroid 1998 8 553-556.

21 Ludgate M, Crisp M, Lane C, Costagliola S, Vassart G, Weetman A et al. The thyrotropin receptor in thyroid eye disease. Thyroid $19988411-413$.

22 Ludgate M, Swillens S, Mercken L \& Vassart G. Homology between thyroglobulin and acetylcholinesterase: an explanation for pathogenesis of Graves' ophthalmopathy? Lancet $19862219-220$.

23 Jacobson DH \& Gorman CA. Endocrine ophthalmopathy: current ideas concerning etiology, pathogenesis, and treatment. Endocrine Reviews 19845 200-220.

24 Ludgate M, Dong Q, Soreq H, Mariotti S \& Vassart G. The pathophysiological significance of a thyroglobulin-acetylcholinesterase shared epitope in patients with Graves' ophthalmopathy. Acta Endocrinologica 1989121 (Suppl 2) 38-45.

25 Mappouras DG, Philippou G, Haralambous S, Tzartos SJ, Balafas A, Souvatzoglou A et al. Antibodies to acetylcholinesterase cross-reacting with thyroglobulin in myasthenia gravis and Graves's disease. Clinical and Experimental Immunology 1995 $100336-343$.

26 Werner SC. Modification of the classification of the eye changes of Graves' disease: recommendations of the Ad Hoc Committee of the American Thyroid Association. Journal of Clinical Endocrinology and Metabolism 197744 203-204.

27 Werner S. Modifications of classification of the eye changes of Graves' disease. American Journal of Ophthalmology $1977 \mathbf{8 3}$ 725-727.

28 Schardt CW, McLachlan SM, Matheson J \& Smith BR. An enzyme-linked immunoassay for thyroid microsomal antibodies. Journal of Immunological Methods 198255 155-168.

29 Laemmli UK. Cleavage of structural proteins during the assembly of the head of bacteriophage T4. Nature $1970 \mathbf{2 2 7} 680-685$.

30 Geysen HM, Rodda SJ, Mason TJ, Tribbick G \& Schoofs PG. Strategies for epitope analysis using peptide synthesis. Journal of Immunological Methods 1987102 259-274.

31 Merrifield RB. Solid phase peptide synthesis I. The synthesis of a tetrapeptide. Journal of the American Chemical Society $1963 \mathbf{8 5}$ 2149-2154

32 Guilbert B, Dighiero G \& Avrameas S. Naturally occurring antibodies against nine common antigens in human sera. Journal of Immunology $1982 \mathbf{1 2 8} 2779-2787$.

33 Male DK, Champion BR, Pryce G, Matthews H \& Shepherd P. Antigenic determinants of human thyroglobulin differentiated using antigen fragments. Immunology $1985 \mathbf{5 4} 419-427$.

34 Saboori AM, Caturegli P, Rose NR, Mariotti S, Pinchera A \& Burek CL. Tryptic peptides of human thyroglobulin: II. Clinical and Experimental Immunology 199498 459-463.

35 Prentice L, Kiso Y, Fukuma N, Horimoto M, Petersen V, Grennan F et al. Monoclonal thyroglobulin autoantibodies: variable region analysis and epitope recognition. Journal of Clinical Endocrinology and Metabolism $1995 \mathbf{8 0} 977-986$.

36 Caturegli P, Mariotti S, Kuppers RC, Burek CL, Pinchera A \& Rose NR. Epitopes on thyroglobulin: a study of patients with thyroid disease. Autoimmunity 199418 41-49.

37 Soreq H, Ben Aziz R, Prody CA, Seidman S, Gnatt A, Neville L et al. Molecular cloning and construction of the coding region for human acetylcholinesterase reveals a G+C-rich attenuating structure. PNAS $1990 \mathbf{8 7} 9688-9692$.

Received 3 November 2000

Accepted 4 April 2001 